adverse conditions. Regulations and remedial measures are to be applied to the existing reserves, such as fencing, irrigation, parcelling out the land for occupational and agricultural use, as well as for rotational cropping and the like, by which it is hoped to introduce into native tribal custom a more economical use of the land. On the new reserves agricultural officers will be appointed to instruct and, if necessary, discipline the natives in modern methods of cultivation. The educational process is bound to be slow; and its success, as previous experiments have shown, will depend very largely upon the discretion with which new methods are welded into traditional custom.

\section{Physics and Society}

IN an address before the American Physical Society, Washington, on April 30, on Science and Society (J. Applied Phys., 8, 373 ; 1937), D. Sarnoff, president of the Radio Corporation of America, referred to the relation of the physicist to the farreaching social changes which follow his discoveries. The radio industry had its origin in the purely theoretical reasoning of Clerk Maxwell when in 1865 he advanced reasons for the existence of electromagnetic waves, although it was only in 1895 that Marconi gave the world a practical system of wireless telegraphy. Already 150 social effects have been traced directly to radio, and the end is not yet in sight. The major obstacles to the public introduction of television no longer lie in the field of research and engineering. The creation of a new art form has demanded new techniques of writing, direction and studio control. Here as elsewhere a scientific approach to the solution of human problems is required, and it is essential that mankind should learn how to use the assets which are the product of the scientific mind. Civilization depends for its advance upon our expanding knowledge of the social as well as of the physical sciences, for no society can solve its problems by intuition or rule of thumb. The advance of social science no less than that of physical science, calls for the creative imagination of a Newton and a Maxwell, an Edison and a Marconi. Obsolescence is a factor in social as well as in industrial machines.

THE social investigator must approach the problems of society in the clear light of an unbiased mind. $\mathrm{He}$ must collect and analyse facts, seek to fathom causes and establish principles, which he must always be willing to reconsider in the light of results. The permanent advance of society depends on our following procedure similar to that of the experienced surgeon. We must not be afraid to operate but must know when a less spectacular and safer treatment will be adequate. Social and economic facts must be investigated, verified and analysed, and the analysis and conclusions disseminated widely by popular education and debate. Industry is continually entering new realms of knowledge, and close understanding and co-operation are required between its leaders and the investigators in the universities.
Industry which has not learnt to employ scientific workers is doomed. Moreover, the problems created by technical science can only be solved by increasing and applying our knowledge of social science, and Mr. Sarnoff urged that the immediate goal of social science should be to achieve economic justice, peace and prosperity in a free democracy. Because that involves collective effort, it does not mean the suppression of individual liberty. Freedom of the individual is essential to the full expression of his creative faculties. Science and society depend upon each other, and when the basic lesson of science, that knowledge of the truth without fear or prejudice is indispensable to progress, is rejected, science-and society with it-goes backward instead of forward.

\section{Education and Training for the Oil Industry}

THE days when a liberal education and an effective personality were sufficient qualifications for entry into the petroleum industry are now over. As Prof. A. W. Nash pointed out in a paper presented to the Chemical Engineering Congress, World Power Conference, 1936 (J. Inst. Pet. Tech., 22; 1936), specialized vocational training is the only adequate background for technical men seeking employment in the industry. Moreover, this specialized training should be directed towards one particular branch of the industry, for example, geology, production, or refining, for in each of these branches different sciences are involved and correspondingly different technical knowledge is necessary for the solution of such problems as may be encountered. Before proceeding to specialize, however, the student must acquire a sound knowledge of the fundamental principles of physics, mathematics and chemistry, together with a working understanding of engineering and chemical engineering. Finally, having mastered these fundamentals and specialized in a particular branch of the industry, the technician should familiarize himself at least with the basic principles underlying the remaining branches of the industry, for in this way alone will he acquire a clear conception of any problem which may present itself from the point of view of the industry as a whole. Universities and other institutions which provide such training for the industry, are fully alive to the fact that, apart from the actual acquisition of knowledge, the student is there primarily to learn how to apply such knowledge, to interpret it and make use of it in the solution of new problems, and their curricula are adjusted accordingly. For the man who has made full use of any such training, there are openings in the industry unrivalled in any other from the points of view of scope and advancement.

\section{The Spread of the Sahara}

There is abundant evidence that early in the Quaternary age the Sahara was inhabited by man and that desiccation has since been proceeding. In so far as this process is one of climatic change, it is beyond the control of man; but there is also much evidence that the increase of desert conditions in both north and south is largely due to human interference. 
In a pamphlet entitled "The Threat of the Sahara", reprinted from the Journal of the Royal African Society, Prof. E. P. Stebbing reviews the available evidence of progressive desiccation and discusses the causes. These can be summarized as war, primitive methods of agriculture, excessive grazing and pasturage and fire. Intertribal warfare has laid waste great tracts and so promoted soil erosion. The method of shifting cultivation, entailing the cutting down of successive areas of forest and their abandonment when annual burning produces too poor a supply of fertilizing wood ash, has allowed the spread of scrub land. This degraded forest is given over to pasturage which tends to destroy the vegetation, the last stage in its use being the pasturing of goats. Prof. Stebbing sees little evidence that the desiccation can be attributed to climatic oscillations, and is extremely doubtful that the succession of a wet period will reverse the present trend.

\section{The Zoological Society of Scotland}

The increase in the number of visitors to the Zoological Park near Edinburgh to just short of half a million, and a surplus on the year's working of $£ 1,708$, indicate the material success of this Society (Ann. Report Zoo. Soc. Scot., 1936-37). In other ways it has made notable progress. The new openair enclosure for tigers, which occupies the site of an old sandstone quarry, is a most striking example of the use of natural rock, and a new restaurant, made necessary by the increase of visitors, has been completed and opened. During the year five king penguin chicks were hatched, of which three were successfully reared, and amongst mammals there were born and reared lion cubs, four beavers, three llamas, a nilghai and Barbary sheep. The chimpanzee born in January 1936 has developed well, and for many years the breeding of tropical freshwater fishes has been a feature of the Carnegie Aquarium. A successful innovation was the holding of a series of meetings of members at which lectures upon, and illustrated accounts of, their investigations of animal habits and behaviour were given by experts.

\section{Survey of India}

IN 1905 the hope was expressed by the Survey of India that in twenty-five years maps of the whole Indian Empire on a scale of one inch to a mile would be available. The Annual Report for 1936 (Calcutta. 2s. $6 d$.) points out that this hope is far from realization, and that a little more than half the area is now mapped on that scale. When it was realized in 1913 that the scheme could not be completed for many years, it was decided to reduce the scale of survey for the less populous areas. As a result, twothirds of the country is now covered by modern maps ranging in scale from one inch to a quarter inch. In the year under review more than fiftythree thousand square miles was surveyed, in addition to a certain amount of revision. The report contains full index sheets to all the scales, including the sheets of the Carte Internationale on a scale of one million which cover India and adjoining lands.

\section{Motor-boat Speed Record}

ON September 1, Sir Malcolm Campbell, driving his new motor-boat Bluebird on Lake Maggiore, made two runs over a measured mile at an average speed of $203.3 \mathrm{~km}$. an hour. His boat is equipped with a single Rolls-Royce engine of 2000 h.p., similar to that of his motor-car Bluebird. Sir Malcolm has thus achieved the distinction of holding the speed record for both land and water.

\section{Announcements}

Mr. J. D. Griffitr Davies, an administrative assistant in the Higher Education Department at Leeds, has been appointed assistant secretary of the Royal Society as from September 1 in succession to Mr. R. Winckworth, who at his own request has reverted to his previous position in charge of the Society's publications.

THE following appointments and promotions have recently been made in the Colonial Service: E. F. Allen, to be agricultural officer, Malaya ; D. B. Fanshawe, to be assistant conservator of forests, British Guiana; D. E. Faulkner, to be veterinary officer, Gold Coast ; K. D. S. MacOwan, to be veterinary officer, Kenya ; J. W. Ewart, to be assistant curator of gardens, Malaya; F. R. Mason (agricultural field officer, Malaya), to be deputy director, Department of Agriculture and Fisheries, Palestine; R. W. R. Miller (director of science and agriculture, Barbados), to be director of agriculture, Zanzibar; W. D. MacGregor (senior assistant conservator of forests), to be conservator of forests, Nigeria; H. G. Wilt. shire (pathologist, Zanzibar), to be senior pathologist, Uganda; W. Horsfield (staff surveyor), to be district surveyor, Lands and Mines Department, Tanganyika; H. M. Pendlebury (curator, Selangor Museum), to be director of museums, Federated Malay States ; J. L. Tetley (assistant analyst, Imports and Exports Department, Hong Kong), to be chemist, Institute for Medical Research, Federated Malay States.

Dr. Robley D. Evans, assistant professor of physics at the Massachusetts Institute of Technology, recently received the first Theobald Smith award in medical science, consisting of a bronze medal and one thousand dollars, for his researches, which have led to a method of detecting radium poisoning before its fatal stage and a treatment for extracting radium from bones.

A USEFUt little volume on most aspects of map. making has been published under the title of "Cartography" (Special Publication No. 205. U.S. Dept. of Commerce. Coast and Geodetic Survey 1936. 60 cents). The pamphlet opens with a short historical survey, after which is a discussion of different kinds of maps and charts and their requirements. Then follows a chapter on compilation of the material for a map and a clear, though brief, account of the chief projections. The last section treats of the technique of construction. There are many reproductions of sections of various maps, American and others. 